\title{
Price Transmission in Yam Markets in Côte d'Ivoire
}

\author{
Eza Soumaley Sylvie ${ }^{1,2} \&$ N'Goran Koffi Celestin ${ }^{3}$ \\ ${ }^{1}$ Félix Houphouët Boigny University, Abidjan, Côte d'Ivoire \\ ${ }^{2}$ Swiss Centre for Scientific Research in Côte d'Ivoire, Abidjan, Côte d'Ivoire \\ ${ }^{3}$ Peleforo Gon Coulibaly University, Korhogo, Côte d'Ivoire \\ Correspondence: Eza Soumaley Sylvie, Swiss Centre for Scientific Research in Côte d'Ivoire, 01 BP 1303 \\ Abidjan 01, Adiapodoumé, km 17, Côte d'Ivoire. Tel: 225-077-870-1183. E-mail: sylvie.eza@csrs.ci; \\ soumaleysylvie@gmail.com
}

Received: August 1, 2021

doi:10.5539/jas.v13n10p152
Accepted: September 2, $2021 \quad$ Online Published: September 15, 2021

URL: https://doi.org/10.5539/jas.v13n10p152

\begin{abstract}
Many studies have shown that rising prices are not transmitted in the same way as falling prices and vice versa. There is an asymmetry in price transmission between agricultural commodity markets that is an important issue in household food security. The main objective of this study is to examine the nature of price transmission in yam markets in Côte d'Ivoire. To do so, two regression models were used, namely the Ordinary Least Squares (OLS) method and Vector autoregressive (VAR) model. The results revealed that a variation in prices on Abengourou and Korhogo markets affects the price on the Abidjan market even though trade between these markets is not direct. Similarly, the price one month later on Abidjan market is affected by its past price and that of Korhogo market one month earlier. As recommendation, the study suggests that the government should strengthen and improve road infrastructure as well as communication networks to enhance trade between markets.
\end{abstract}

Keywords: price transmission, yam market, Côte d'Ivoire

JEL: C22, C32

\section{Introduction}

The analysis of price transmission in markets has been widely discussed in economics and particularly in agricultural economics. In this analysis, the nature of price transmission, i.e. whether it is symmetrical or not (asymmetrical), has been highlighted. This transmission character is perceived at the level of market integrations. The presence of asymmetry in the transmission of prices between markets generally raises the issue of market failure (Meyer \& Cramon-Taubadel, 2004). Transmission asymmetry indicates that price increases in one market are not transmitted in the same way to another market as price decreases. It can also be observed when a price in one market rises faster than it falls or when the speed of price adjustment at equilibrium differs from one market to another (Meyer \& Cramon-Taubadel, 2004).

Two main reasons have been suggested for this asymmetry in price transmission. The market power of actors in the markets (Meyer \& Cramon-Taubadel, 2004; Fiamohé \& De Frahan, 2012) and transaction costs (Brosig et al., 2011; Fiamohé et al., 2013). Both factors are identified in the analysis of price transmission between international and local markets and between local markets themselves in developed and developing countries.

In our case, we focus on price transmission between local food markets in Côte d'Ivoire. Some studies have analysed price transmission between local markets but only for products such as cereals (rice and maize) and plantain (Sobia, 2003; Keho \& Camara, 2012; Keho \& Sobia, 2013).

The objective of this paper is to analyse and examine price transmission in yam markets in Côte d'Ivoire. To do so, the paper is organized in four sections. The first section presents a review of theoretical and empirical studies on price transmission. The second section discusses the methodology. The results and discussion are in the third section. The fourth section concludes and gives recommendations. 


\section{Literature Review}

Price transmission between markets takes on a different dimension depending on the trading framework. Trade takes place at several levels: i) between markets of member countries of the same community (regional markets), ii) between international (world) and national (domestic) markets and iii) between local markets within a country. At each level of trade, specific factors influence the transmission of prices making it asymmetric.

In paradigmatic price theory, changes in input prices are likely to be transmitted in proportional changes in marginal costs and hence prices. These variations are expected to be symmetric and reversible (Peltzman, 2000; Saha \& Mitura, 2008). This is possible if we are in a situation of perfect competition. In reality, markets are not always competitive. Therefore, the transmission of prices between markets is asymmetric. Rising prices are generally transmitted faster than falling ones (Peltzman, 2000; Saha \& Mitura, 2008; Toolsema \& Jacobs, 2007; Kimmel, 2009). The recurrent explanation for this is related to the behaviour of actors who exercise market power and the costs of adjustment.

In empirical studies, two major factors have been found to cause asymmetric price transmission between agricultural markets, namely market power and high transaction costs. These factors are more present in vertical and horizontal price transmission between markets. Vertical price transmission refers to the relationship between the links in the supply chain. Horizontal transmission refers to the relationship between spatially separate markets.

Blažková and Syrovátka (2012) assessed price transmission along the wheat production chain in the Czech Republic based on two products: wheat flour and bread. The results showed that for both flour and bread there is an asymmetric transmission of prices from the processor to the retailer and from the farmer to the processor respectively. The main explanation is that these actors have some power in the market through their organization. Similarly, they pointed out that labour, energy and marketing costs are factors that make price transmission asymmetric between the different links in the supply chain in the wheat and flour markets.

Sobia and Keho (2013), also conducted a similar analysis of the relationship between the wholesale and retail markets for rice and maize. It was also found that the market power of wholesalers in the market influences the transmission of the wholesale price to the retail price.

Keho and Camara (2012) analyse the vertical relationships between wholesale and retail prices in three important local rice markets in Côte d'Ivoire. The results show the asymmetric transmission of prices in the markets. Increases in wholesale prices are passed on to retail prices more quickly than decreases. The results also show that the speed and magnitude of the response of retail prices to changes in wholesale prices is much higher for Abidjan market than for Bouaké market. This is consistent with the fact that Abidjan market is primarily a consumer market and has a higher trade intensity than Bouaké market, which is both a consumption and production area. However, these results imply neither market power nor supra-normal profits among traders in Abidjan and Bouaké markets.

Saha and Mitura (2008) analysed the dynamics of price transmission in markets along the beef supply chain. The results indicate that retail prices adapt more quickly and are relatively more extensively to increases than to decreases in processing prices. Processing prices also adjust similarly to increases in farm prices for beef cattle in Ontario and Quebec. This asymmetry may be a result of the imperfect retail beef market in these provinces.

Fiamohé and De Frahan (2012) state that in the markets for the main commodities in Benin (maize, cassava semolina and yam), price transmission between assembly premises markets and consumer markets is asymmetric. Indeed, the results of the study indicate that most prices in the assembly markets considered adjust more quickly to consumer market prices than in the opposite direction. This is due to the fact that in assembly markets, traders are organized in associations.

Subervie (2007) shows that traders behave as oligopolists on the assembly markets in order to correct the imbalances that lead their selling price below the equilibrium value. Furthermore, agreements between traders to maintain a certain price in the markets influence the imperfect transmission of prices.

Abdulai (2002) explains that agreements between traders in rural grain (maize) markets in Ghana allow them to maintain their selling price at a certain level even when events occur that could lead to a drop in this price. Sometimes these traders position themselves as essential buyers from their suppliers by pre-financing them. This positioning can lead to an incomplete transmission of prices between markets.

Most often these high transaction costs are due to the location of many villages in the province in relation to information and road access (Brosig et al., 2011). Thus, after analysing the spatial transmission of prices between 
wheat markets in 28 provinces in Turkey, these authors found that minimum transaction costs, very often hinder the full integration of small markets than large ones.

One finding is that high transaction costs prevent producers from accessing markets and cause asymmetric price transmission (Fiamohe et al., 2013). Thus, after examining price transmission between local paired (producer and consumer) rice markets in Benin and Mali; the results show that in Benin, price transmission between markets in the production area and consumer markets is asymmetric. That is, price increases in the markets of surplus areas are transmitted more quickly to consumer markets than price decreases. This asymmetry is explained by high transaction costs.

In Ethiopia, market power is also present in some markets, notably wholesale markets, which most often influence prices in local markets (Getnet et al., 2005). Indeed, in a context of agricultural market liberalization policy Getnet et al. analyse the spatial transmission of prices between grain markets in Ethiopia. The results show that the wholesale price of cereals on the central consumer market plays a determining role in the short and long term of the producer price on the local supply markets. This is because the central wholesale market has a certain power over local markets that keep small-scale producers vulnerable to low and unstable prices.

Another important factor related to the conservation of products affects the stability of prices on the markets. This is the perishability of the products, which influences the behaviour of the actors in setting prices downwards for rapid disposal in order to avoid losses. Indeed, the price dynamics of vegetables (tomato and cauliflower) on European markets have been analysed (Santeramo, 2015). It was found that EU markets are integrated and price signals are transmitted within a few weeks. Price increases are transmitted within two to three weeks. While price decreases are transmitted within one week. These results can be explained by the perishability of the products. The perishability of the products has a downward effect on prices due to the lack of storage. However, the price increase due to a limited harvest is transmitted slowly, resulting in a low interest of the actors in remote areas. In addition, the fact that the products are perishable fully transmits price variations to the markets. Indeed, in the case of lettuce, the transmission of shocks is stronger in the case of a price decrease than in the case of an increase (Besson, 2008).

Other studies have identified that trade policies implemented by state authorities are also a source of imperfect price transmission in local agricultural markets. These policies include the development of communication infrastructure. Etoundi (2011) has shown that communication infrastructure plays a role in the poor integration of local tomato markets in Cameroon. Indeed, with the development of these infrastructures, traders prefer to sell in border countries rather than selling in local markets. As a result, local markets in Cameroon are integrated over the long term. The speed of adjustment to negative shocks is faster than that of adjustment to positive shocks in some markets. In this case, there is an asymmetry in price transmission. Retailers pass on decreases in shipping prices to consumers more quickly than increases.

Similarly, Ihle et al. (2010) show in a study in Ghana that it is not direct trade that indicates market integration. Markets can be integrated even without trade. Indeed, in the presence of direct trade, the two main tomato production markets respond to price changes relative to the consumer markets. The authors point out that overall, price transmission in the markets appears to be rapid with an adjustment lasting a few weeks. Similarly, in the absence of trade, production markets react to price imbalances. The effect of prices between markets when there is no direct exchange is possible thanks to the means of telephone communication available to the actors on the markets.

In the light of our review, we note that in addition to the main factors causing asymmetry in price transmission, other factors have emerged. These include the perishability of products and the trade policies implemented by governments. In our study, we are interested in analysing the horizontal transmission of prices between local production (food product surplus) and consumption (food product deficit) markets.

\section{Methodology}

\subsection{Model Specification}

In this section we look at the effect of price variation between two types of markets. The markets located in the production areas and the central consumer market. To do so, we consider the following simple linear relationship between the two price series $P C_{t}$ and $P Z P_{t}$ :

$$
P C_{t}=\alpha+\beta P Z P_{t}+\mu_{t}
$$

where, $P C_{t}$ is the price on the consumption market (Abidjan market), $P Z P_{t}$ denotes the price on markets close to the production areas. The coefficient $\alpha$ represents the constant term and $\mu_{t}$, is the error term. 
Beforehand, stationarity tests will be performed to identify the appropriate model for the analysis of the relationship between the markets. The result of these tests will show the level of stationarity of the studied series.

\subsection{Data Source}

Monthly wholesale yam price series data (kponan) covering the period from 2012 to 2018 were utilized. The selected markets are Abidjan consumer market and markets close to the production areas (Bouaké, Bondoukou, Abengourou and Korhogo). The data base comes exclusively from the Assistance Office for Commercialization of Food Products (OCPV). This structure is spread throughout the country. It collects the prices of food products twice a week on the markets and produces a monthly database. In addition, the variables used in model (1) are the price series on the markets of Abidjan, Bouaké, Bondoukou, Abengourou and Korhogo.

\subsection{Analysis of Descriptive Statistics}

The results of descriptive statistics for our variables are collated in Table 1. It shows sample means, standard deviations, skewness, probabilities (p-value), Jarque Bera statistic and kurtosis.

Table 1. Descriptive statistics for yam prices by market

\begin{tabular}{llllll}
\hline & Abidjan & Abengourou & Bondoukou & Bouaké & Korhogo \\
\hline Mean & 384.7246 & 241.0238 & 311.5453 & 348.0637 & 382.1602 \\
Median & 359.5833 & 227.0000 & 311.1111 & 300.0000 & 329.5000 \\
Maximum & 687.5000 & 500.0000 & 526.0000 & 757.0000 & 960.0000 \\
Minimum & 204.1667 & 150.0000 & 100.0000 & 175.0000 & 200.0000 \\
Std.Dev & 119.5061 & 69.44475 & 95.29935 & 133.8496 & 158.069791 \\
Skeweness & 0.589152 & 1.251500 & -0.327310 & 1.219549 & 2.069791 \\
Kurtosis & 2.335004 & 4.743205 & 2.504942 & 3.707501 & 7.341434 \\
Jarque-Bera & 6.407171 & 32.56320 & 2.357638 & 22.57415 & 125.9447 \\
Probability & 0.040616 & 0.000000 & 0.307642 & 0.000013 & 0.000000 \\
Sum & 32316.86 & 20246.00 & 26169.81 & 29237.35 & 32101.46 \\
Sum Sq.Dev. & 1185381.0 & 400273.6 & 753803.2 & 1487004.0 & 2073784.0 \\
Observations & 84 & 84 & 84 & 84 & 84 \\
\hline
\end{tabular}

Source: OCPV data, construction of the author.

Reading Table 1 shows that the yam prices on the markets of Abidjan (384 FCFA/Kg or $0.686 \mathrm{USD} / \mathrm{Kg}$ ), Korhogo (382 FCFA/Kg or $0.682 \mathrm{USD} / \mathrm{Kg}$ ), Bouaké (348 FCFA/Kg or $0.622 \mathrm{USD} / \mathrm{Kg}$ ) and Bondoukou (311 FCFA $/ \mathrm{Kg}$ or $0.556 \mathrm{USD} / \mathrm{Kg}$ ). All are higher than that of Abengourou (241 FCFA/Kg or $0.431 \mathrm{USD} / \mathrm{Kg}$ ).

As for the maximum price, the markets of Korhogo (960 FCFA / Kg or $1.716 \mathrm{USD} / \mathrm{Kg}$ ), Bouaké (757 FCFA/Kg or $1.353 \mathrm{USD} / \mathrm{Kg}$ ) and Abidjan (687 FCFA $/ \mathrm{Kg}$ or $1.228 \mathrm{USD} / \mathrm{Kg}$ ) have high prices. While we have low prices in the markets of Bondoukou (526 FCFA/Kg or $0.62 \mathrm{USD} / \mathrm{Kg}$ ) and Abengourou (500 FCFA/Kg or $0.894 \mathrm{USD} / \mathrm{Kg}$ ) have the lowest prices.

The minimum prices follow the same dynamic, but this time starts with the markets of Abidjan (204 FCFA/Kg or $0.365 \mathrm{USD} / \mathrm{Kg}$ ) and Korhogo (200 FCFA $/ \mathrm{Kg}$ or $0.357 \mathrm{USD} / \mathrm{Kg}$ ) where the prices are the highest. Bouaké (175 FCFA $/ \mathrm{Kg}$ or $0.313 \mathrm{USD} / \mathrm{Kg}$ ), Abengourou $(150 \mathrm{FCFA} / \mathrm{Kg}$ or $0.268 \mathrm{USD} / \mathrm{Kg}$ ) have lower prices compared to the first markets. However, Bondoukou (100 FCFA/Kg or $0.179 \mathrm{USD} / \mathrm{Kg}$ ) have the lowest prices.

Moreover, in terms of standard deviations, the markets of Korhogo (158.07), Bouaké (133.85) and Abidjan (119.50) have the highest standard deviations. While the lowest are for the Bondoukou (95.30) and Abengourou (69.44) markets.

\subsection{Analysis of the Evolution of Kponan Yam Prices on the Markets}

Figure 1 shows the evolution of the monthly price series of kponan yam on the five markets covering the period from 2012 to 2018. 


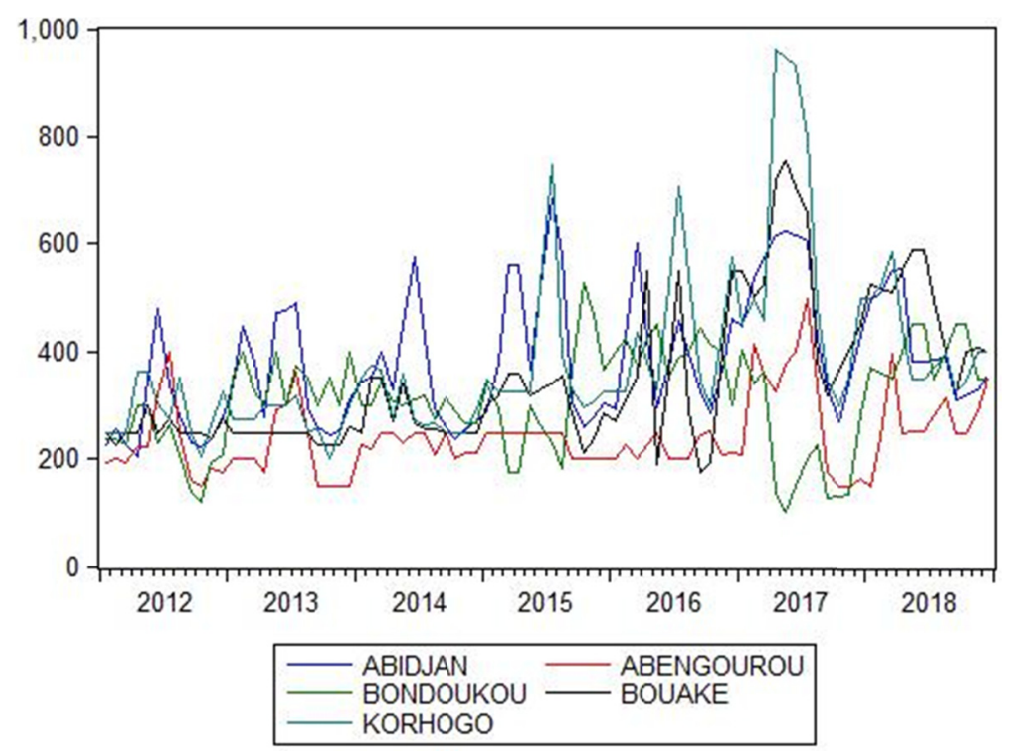

Figure 1. Evolution of the price of kponan yam on the markets

Source: OCPV data, construction of the author.

Overall, the price series irregularly evolve. We observe price differences at certain periods for the markets in Abidjan, Korhogo and Bouaké. From 2013 to 2015, in some months, the price on the Abidjan market is higher than on the other four markets. Similarly, from 2015 to 2017, the price on the Korhogo market peaks. However, in 2017, prices on Abidjan, Bouaké and Korhogo markets show the same upward trend as prices on Bondoukou and Abengourou markets. Even at this level, the price gap on Korhogo market is larger. The figure also suggests that the price series of the different markets do not necessarily vary with time. In this case, we can assume that the series are stationary. However, the unit root tests will confirm this assumption. In fact, unit root tests make it possible to verify the stationarity of the series, that is to say if the series do not vary as a function of time. The identification of stationarity allows the choice of the best model to use for the study.

\subsection{Stationarity Test}

To make the choice of the study model, we performed the Dickey-Fuller (ADF) and Phillip-Perron (PP) Augmented Univariate Unit Root Tests following the methodology of the Dickey and Fuller (1979) and Phillips-Perron (1988) approach. The results are presented in Table 2.

Table 2. Unit root test

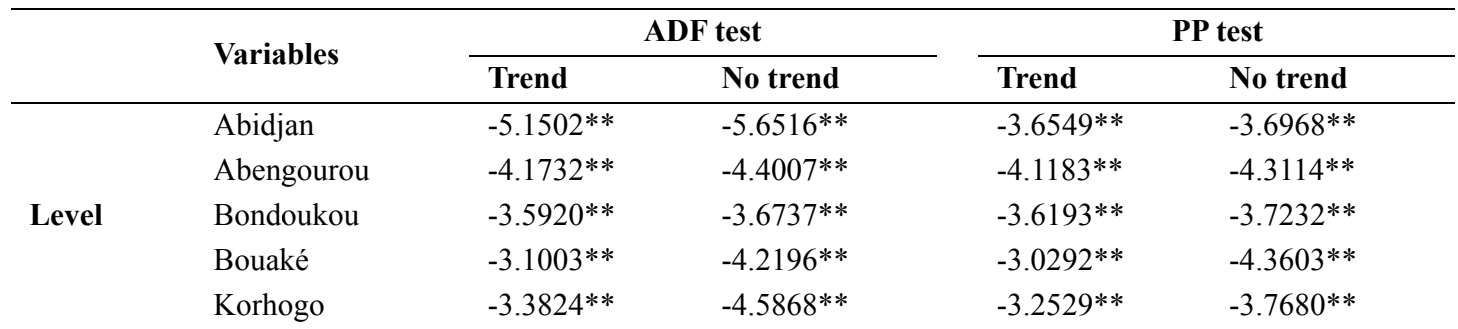

Note. ${ }^{* *}$ indicates significance at the $5 \%$ level. Mickinnon (1980) critical values used for rejection of the null unit root.

Source: OCPV data, construction of the author.

Overall, we notice that all price series are stationary at level. Therefore, we can conclude that all series are integrated of order $(0)$. This means that there is no cointegration relationship between the series. In this case, the appropriate analysis methods are among others the OLS method and the VAR model. This means that the relationship between the markets through their current prices and those of previous periods can be studied. 


\section{Results and Discussions}

This section presents the estimates results according to the Ordinary Least Squares (OLS) and Vector Autogressive (VAR) approaches.

Regarding the Ordinary Least Squares (OLS) method, model (1) was estimated and result of the final estimate are presented in table 3 . We note that the presence of autocorrelation in the residuals of our estimation has been corrected by the ARMA (1.1) process. Table 3 shows that the adjusted $\mathrm{R}^{2}$ has a value of 0.67 , which means that the explanatory variables considered in the model, explain $67 \%$ of the variations in the price of yam on Abidjan market. The value of the Fisher statistic reports 43.52259 with a zero probability which shows that the model is well specified or that the model is globally significant. Moreover, the value of the DW statistic (1.98) which is close to 2, we can conclude the absence of autocorrelation in the residuals. Finally, we note that all the variables are significant as well as the MA process at the 5\% threshold. The significance of the MA indicates that the autocorrelation is partial.

We note that the variation of the price on Abengourou market influences that of the Abidjan market at $39 \%$. While the variation of the price on Korhogo market affects at $35 \%$. In other words, one could say that if the price on Abengourou market increases by $100 \mathrm{FCFA} / \mathrm{kg}$ or $0.179 \mathrm{USD} / \mathrm{Kg}$, the price on the Abidjan market increases by $39 \mathrm{FCFA} / \mathrm{Kg}$ or $0.070 \mathrm{USD} / \mathrm{Kg}$. Similarly, if the price on Korhogo market increases by $100 \mathrm{FCFA} / \mathrm{Kg}$ or $0.179 \mathrm{USD} / \mathrm{Kg}$, the price on the Abidjan market increases by $35 \mathrm{FCFA} / \mathrm{Kg}$ or $0.063 \mathrm{USD} / \mathrm{Kg}$. The relationship between these markets could be explained by the fact that Abengourou and Korhogo markets are close to the production areas. Indeed, Abengourou is on the Bondoukou-Abidjan axis, and this market could be influenced by Bondoukou market, which is a major production and supply area for Kponan yam (Mahyao, 2008). Similarly, Korhogo is also close to major yam production areas. This could be one of the reasons for the influence of prices in this market.

However, the percentages of variation are low, which could be due to the fact that the markets are not directly linked. In reality, Korhogo market is directly linked to Bouaké market, which represents a redistribution market for other markets, particularly in Abidjan. Abengourou market, on the other hand, could have a direct link, but this is weak. Ultimately, there is a transmission of prices from Abengourou and Korhogo markets to the Abidjan market. This means that the markets are integrated even if the trade is not direct. There could be a good flow of information through the communication networks. Indeed, the development of telephone networks allows for the exchange of information between actors, thus leading to market integration. This result is consistent with that of Ihle et al (2010). These authors have shown that in the tomato market in Ghana, markets are highly integrated even when they do not trade directly. The same is true of the work of Etoundi (2011) who states that the development of communication infrastructure (telephone networks) favours the integration of tomato markets in Cameroon.

Table 3. Final estimation of model (1) by the OLS mehod

\begin{tabular}{|c|c|c|c|c|}
\hline Variables & Coefficients & Std.Error & t-Statistic & Probability \\
\hline $\mathrm{C}$ & 156.6968 & 40.73428 & 3.846804 & 0.0002 \\
\hline Abengourou & 0.390896 & 0.150647 & 2.594785 & 0.0113 \\
\hline Korhogo & 0.352407 & 0.073613 & 4.787304 & 0.0000 \\
\hline $\mathrm{AR}(1)$ & 0.226554 & 0.174669 & 1.297045 & 0.1984 \\
\hline MA (1) & 0.489581 & 0.155181 & 3.154909 & 0.0023 \\
\hline R-squared & 0.690587 & \multicolumn{2}{|c|}{ Mean dependent var } & 386.6480 \\
\hline Adjusted R-squared & 0.674720 & \multicolumn{2}{|c|}{ S.D. dependent var } & 118.9172 \\
\hline S.E. of reggression & 67.82246 & \multicolumn{2}{|c|}{ Akaike info criterion } & 11.33001 \\
\hline Sum squared resid & 358791.1 & \multicolumn{2}{|c|}{ Schwarz criterion } & 11.47573 \\
\hline Log likelihood & -465.1956 & \multicolumn{2}{|c|}{ Hannan-Quinn criter } & 11.38855 \\
\hline F-statistic & 43.52259 & \multicolumn{2}{|c|}{ Durbin-Watson stat } & 1.987278 \\
\hline Prob (F-statistic) & 0.000000 & & & \\
\hline
\end{tabular}

Source: OCPV data, construction of the author.

We then perform the same model (1) with the vector autoregressive approach. This procedure allows us to identify the dynamic relationship between the variables. The estimation results are discussed in Table 4 . 
Beforehand, we determine the appropriate number of lags that a parameter is important in VAR modelling. The optimal number of lags can be selected using the available lag number selection criteria. The most common criteria are the Akaike Information Criterion (AIC), the Schwartz Bayesian Criterion (SBC) and the Hannan Quinn Criterion (HQC). For a maximum delay of 4 we obtain Table 4. According to the observation of the table, the LR, FPE, AIC and HQ criteria select two lags to model the dynamic interrelations between the prices of Abengourou and Korhogo markets and Abidjan market. However, according to the SC criterion, one lag is sufficient. In view of these results, two lags are retained for the estimation of the VAR.

Table 4. Information criteria for the choice of delay in the VAR model

\begin{tabular}{lllllll}
\hline Lag & LogL & LR & FPE & AIC & SC & HQ \\
\hline 0 & -1424.290 & NA & $6.30^{\mathrm{e}}+11$ & 35.68225 & 35.77158 & 35.71807 \\
1 & -1362.696 & 117.0289 & $1.69^{\mathrm{e}}+11$ & 34.36740 & $34.72470^{*}$ & 34.51065 \\
2 & -1348.956 & $25.07483^{*}$ & $1.50^{\mathrm{e}}+11^{*}$ & $34.24891^{*}$ & 34.87419 & $34.49960^{*}$ \\
3 & -1342.502 & 11.29448 & $1.61^{\mathrm{e}}+11$ & 34.31256 & 35.20582 & 34.67069 \\
4 & -1334.137 & 14.01197 & $1.64^{\mathrm{e}}+11$ & 34.32842 & 35.48966 & 34.79400 \\
\hline * indicates lag order selected by the criterion & & & & \\
LR: sequential modified LR test statistic (each test at 5\% level) & & & \\
FPE: Final prediction error & & & & \\
AIC: Akaike information criterion \\
SC: Schwarz information criterion \\
HQ: Hannan-Quinn information criterion
\end{tabular}

Source: OCPV Data, construction of the author.

We estimate the VAR model by considering two lags. Table 5 shows us that the model is globally significant as the F-Statistic is 18.01688 and at almost zero probability. The adjusted coefficient of determination $\mathrm{R}^{2}$ is above $50 \%$ or $55 \%$, i.e., the explanatory variables explain $55 \%$ of the model. The value of the DW statistic (1.91) which is close to 2, we can conclude that there is no autocorrelation in the residuals. The model is globally significant because the F-Statistic is 18.01688 and has a zero probability.

It can be seen that the past price of one month on Abidjan market influences that of the following month by $68 \%$. In other words, an increase in the price of one month of $100 \mathrm{FCFA} / \mathrm{Kg}$ or $0.179 \mathrm{USD} / \mathrm{Kg}$ on Abidjan market also causes an increase of $68 \mathrm{FCFA} / \mathrm{Kg}$ or $0.122 \mathrm{USD} / \mathrm{Kg}$ on the same market the following month. Similarly, one month's past price on Korhogo market affects the next month's price on the Abidjan market by $30 \%$. In other words, if one month's past market price in Korhogo increases by $100 \mathrm{FCFA} / \mathrm{Kg}$ or $0.179 \mathrm{USD} / \mathrm{Kg}$, the next month's market price in Abidjan increases by $30 \mathrm{FCFA} / \mathrm{Kg}$ or $0.054 \mathrm{USD} / \mathrm{Kg}$. These results show us that the future price on Abidjan market is mainly influenced by its past price of one month. This confirms the assertion of David-Benz et al. (2010). These authors state that when the price series studied are integrated of order zero or $\mathrm{I}(0)$, they are essentially explained by their past values and the introduction of other identified variables. Indeed, there is a strong influence of past prices on future prices in the same market. The past price is just one month older. The possible explanation for this impact is that the price set one month ago is fresh in the memory of the protagonists (sellers and buyers) and therefore represents a reference for setting the new price. 
Table 5. Final estimation of the VAR model

\begin{tabular}{|c|c|c|c|c|}
\hline Variables & Coefficients & Std.Error & t-Statistic & Probability \\
\hline $\mathrm{C}$ & 166.0089 & 37.78266 & 4.393785 & 0.0000 \\
\hline Abidjan (-1) & 0.686848 & 0.127489 & 5.387503 & 0.0000 \\
\hline Abidjan (-2) & -0.251387 & 0.128784 & -1.952010 & 0.0547 \\
\hline Abengourou (-1) & 0.097472 & 0.185857 & 0.524446 & 0.6015 \\
\hline Abengourou (-2) & -0.136094 & 0.179573 & -0.757877 & 0.4509 \\
\hline Korhogo $(-1)$ & 0.303250 & 0.098858 & 3.067538 & 0.0030 \\
\hline Korhogo (-2) & -0.141018 & 0.102756 & -1.372358 & 0.1740 \\
\hline R-squared & 0.590391 & \multicolumn{2}{|c|}{ Mean dependent var } & 388.2281 \\
\hline Adjusted R-squared & 0.557622 & \multicolumn{2}{|c|}{ S.D. dependent var } & 118.7692 \\
\hline S.E. of reggression & 78.99516 & \multicolumn{2}{|c|}{ Akaike info criterion } & 11.65815 \\
\hline Sum squared resid & 468017.7 & \multicolumn{2}{|c|}{ Schwarz criterion } & 11.86360 \\
\hline Log likelihood & -470.9842 & \multicolumn{2}{|c|}{ Hannan-Quinn criter } & 11.74064 \\
\hline F-statistic & 18.01688 & \multicolumn{2}{|c|}{ Durbin-Watson stat } & 1.914180 \\
\hline Prob (F-statistic) & 0.000000 & & & \\
\hline
\end{tabular}

Source: OCPV data, construction of the author.

Finally, we evaluate model (1) for both approaches using the diagnostic tests. Figures 2 and 3 show the CUSUM statistics that measure the structural stability mode. As we see, the statistics remain within the confidence interval, so we reject the null hypothesis of structural change over time. Furthermore, the figures show overall stability of the coefficients in the model.

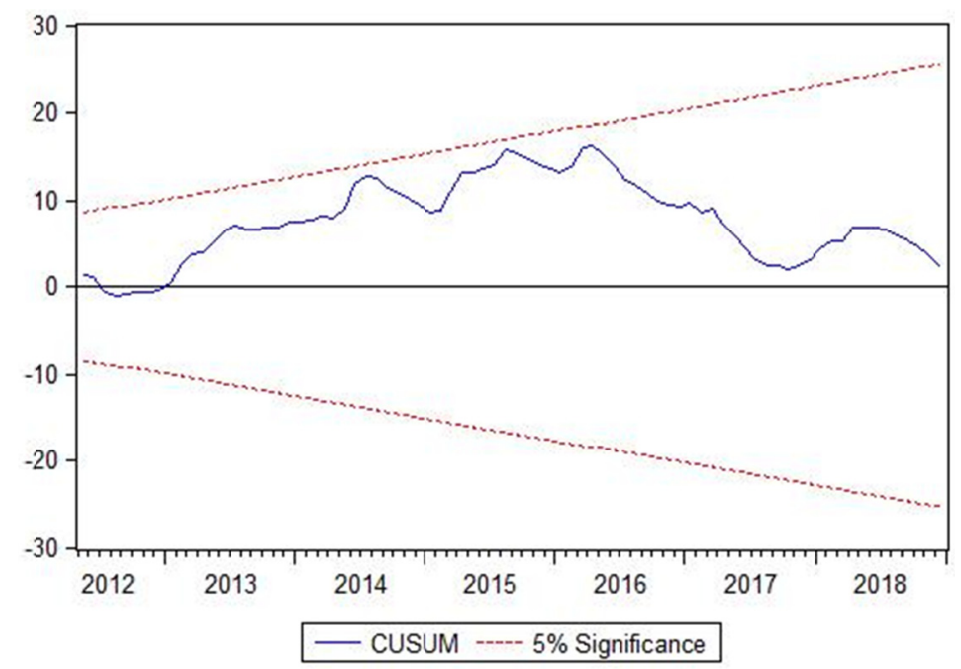

Figure 2. CUSUM test for the OLS method

Source: OCPV data, construction of the author. 


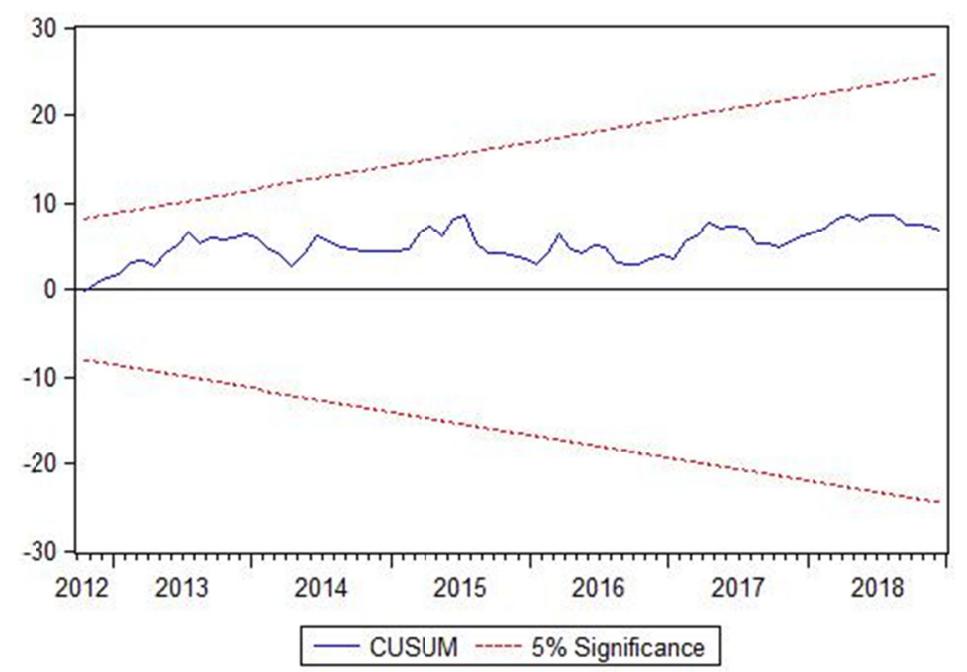

Figure 3. CUSUM test for the VAR model

Source: OCPV data, construction of the author.

\section{Conclusion and Recommendations}

This paper has examined the nature of price transmission in Kponan yam markets in Côte d'Ivoire. The focus has been on the analysis of horizontal price transmission using time series data covering the period from 2012 to 2018. Eviews 7 software was used for our econometric analysis. Unit root tests were performed to check the stationarity of our database. Two methods of analysis were used, namely the Ordinary Least Squares (OLS) method and the VAR model approach. The first method allowed us to identify the relationship between the markets and the second the relationship of these markets with the temporal dynamics of their past prices. The choice of these two methods was based on the identification of the stationarity of the studied price series. The stationarity tests showed that our series are stationary at level and that they are integrated of order $(0)$.

Thus, two major results have emerged in this paper. The first is the influence of kponan yam prices on Abengourou and Korhogo markets on Abidjan market. This result points to a possible integration between the Abidjan market and those of Abengourou and Korhogo. The second result concerns the temporal interaction of prices on the markets. It was found that future prices on the three markets are affected by their past price of one or two months. The future price on the Abidjan market is influenced both by its past price and by the past price of Korhogo market.

These results show that the development of communication networks (telephone) and road infrastructure is important for exchanges between markets. This promotes the exchange of information between market players. Thus, state authorities should develop roads and facilitate the development of telephone networks. In addition, price dynamics in food markets should be taken into account in price stability reforms.

In addition, advanced research could help identify benchmark and secondary markets on the one hand. On the other hand, it would be possible to identify the organization and the implemented strategies (price fixing) by the different market players. In short, to verify the symmetry or asymmetry of price transmission on the yam markets.

\section{References}

Abdulai, A. (2002). Using threshold cointegration to estimate asymmetric price transmission in the Swiss pork market. Applied Economics, 34(6), 679-687. https://doi.org/10.1080/00036840110054035

Besson, É. (2008). Formation des prix alimentaires. Secretariat, Premiere Ministre. Decembre.

Blažková, I., \& Syrovátka, P. (2012). Price formation and transmission along the food commodity chain. Acta Universitatis Agriculturae et Silviculturae Mendelianae Brunensis, 60(4), 31-36. https://doi.org/10.11118/ actaun201260040031 
Brosig, S., Glauben, T., Götz, L., Weitzel, E., \& Bayaner, A. (2011). The Turkish wheat market: Spatial price transmission and the impact of transaction costs. Agribusiness, 27(2), 147-161. https://doi.org/10.1002/ agr.20257

David-Benz, H., Diallo, A., Lançon, F., Meuriot, V., Rasolofo, P., Temple, L., \& Wane, A. (2010). L'imparfaite transmission des prix mondiaux aux marchés agricoles d'Afrique Subsaharienne.

Etoundi, N., Mireille. (2011). Intégration des marchés de production et de consommation au Caméroun.

Fiamohe, R., Seck, P. A., Alia, D. Y., \& Diagne, A. (2013). Price transmission analysis using threshold models: An application to local rice markets in Benin and Mali. Food Security, 5(3), 427-438. https://doi.org/ 10.1007/s12571-013-0254-z

Getnet, K., Verbeke, W., \& Viaene, J. (2005). Modeling spatial price transmission in the grain markets of Ethiopia with an application of ARDL approach to white teff. Agricultural Economics, 33(s3), 491-502. https://doi.org/10.1111/j.1574-0864.2005.00469.x

Ihle, R., Amikuzuno, J., \& Cramon-Taubadel, S. von. (2010). L'intégration des marchés avec et sans échanges commerciaux directs: Le cas de la tomate au Ghana. Revue d'Économie du Développement, 18(1), 21-46. https://doi.org/10.3917/edd.241.0021

Keho, Y., \& Camara, A. S. (2012). Vertical Price Transmission in Local Rice Markets in Côte d'Ivoire: Are Consumers Really Right? Asian Journal of Agriculture and Rural Development, 2(393-2016-23877), $552-564$

Keho, Y., \& Sobia, C. A. (2013). La transmission des prix dans les filières de produits vivriers en Côte d'Ivoire (Rapport d'Étape No. 1, p. 34). Consortium pour la Recherche Economique en Afrique (CREA), Nairobi, Kenya.

Kimmel, S. (2009). Why prices rise faster than they fall. SSRN. https://doi.org/10.2139/ssrn.1435072

Mahyao, A. G. (2008). Etude de l'efficacité du système d'approvisionnement et de distribution des ignames precoces kponan à travers le circuit Bouna-Bondoukou-Abidjan en Côte d'Ivoire (Thèse de Doctorat, Université de Cococdy, Abidjan).

Meyer, J., \& Cramon-Taubadel, S. (2004). Asymmetric price transmission: A survey. Journal of Agricultural Economics, 55(3), 581-611. https://doi.org/10.1111/j.1477-9552.2004.tb00116.x

Peltzman, S. (2000). Prices rise faster than they fall. Journal of Political Economy, 108(3), 466-502. https://doi.org/10.1086/262126

Saha, B., \& Mitura, V. (2008). Transmission des prix le long de la chaîne d'approvisionnement en boeuf canadien et incidence de l'ESB. Statistique Canada, Division de l'Agriculture.

Santeramo, F. G. (2015). Price transmission in the European tomatoes and cauliflowers sectors. Agribusiness, 31(3), 399-413. https://doi.org/10.1002/agr.21421

Subervie, J. (2007). La transmission de l'instabilité des prix agricoles internationaux et ses conséquences dans les pays en développement. Université d'Auvergne-Clermont-Ferrand I.

Toolsema, L. A., \& Jacobs, J. P. (2007). Why do prices rise faster than they fall? With an application to mortgage rates. Managerial and Decision Economics, 28(7), 701-712. https://doi.org/10.1002/mde.1382

\section{Copyrights}

Copyright for this article is retained by the author(s), with first publication rights granted to the journal.

This is an open-access article distributed under the terms and conditions of the Creative Commons Attribution license (http://creativecommons.org/licenses/by/4.0/). 